\title{
The Influence of Private Label on Customer Loyalty, the Mediating Role of Customer Satisfaction
}

\author{
JAMAL M. M. JOUDEH ${ }^{1}$, TAREQ N. HASHEM ${ }^{2}$, NAWRAS M. NUSAIRAT ${ }^{1}$ \\ ${ }^{1}$ Marketing Department, Applied Science Private University, JORDAN \\ ${ }^{2}$ Marketing Department, Isra University, Amman, JORDAN
}

\begin{abstract}
Current study aimed at examining the influence of PL on customer loyalty through the mediating factor of customer satisfaction. Depending on quantitative approach; and distributing (197) questionnaires on individuals; results of study indicated that private label has the ability to increase loyalty if it was accompanied by high customer satisfaction. Among variables chosen, it appeared that product quality and store followed by price are influential in increasing satisfaction and leading to better loyalty. Study recommended taking extra attention in managing and manufacturing private brands in order to increase loyalty through satisfying customers.
\end{abstract}

Key-Words: - Label, Private Label, Private Brand, Customer Loyalty, Customer Satisfaction, retail stores

Received: October 31, 2019. Revised: May 2, 2020. Accepted: May 12, 2020. Published: May 22, 2020.

\section{Introduction}

The brand plays a large and important role in the commercial field in all countries of the world, especially in the field of internal and external trade. It has been agreed to define the brand as all that distinguishes a product or service from other similar or similar goods or services. The brands take forms and are made up of many elements that are difficult to enumerate. Therefore, in most trademark legislation and methods of protection, the legal legislator cited examples of what the trademark might include names, figures, drawings, symbols, addresses of shops, prominent inscriptions and a group of colors that take a special form, as well as any combination of these elements.

According to Kokilavizhi and Vanitha (2018) technology and internet have played a role in increasing the awareness of customer regarding the private brand, it also played a role in increasing the interest of retailors on the benefits of having a private label that is custom designed for them. On the other hand, Kumar and Kothari (2015) pointed out that the customers' perception regarding the idea of private label became more apparent with the awareness of customers' regarding the ability of the private label to serve them and give them the best of their payment. Authors also added that having a good level of customer satisfaction regarding a private label brand can be considered as a good indicator for an upcoming customer loyalty that would appear along with the increased satisfaction.

Based on the above argument, current study seeks to examine the influence of private label on customer loyalty with the mediating factor of customer satisfaction. Researcher hypothesize that the good level of satisfaction that private label may develop among customers can be a good approach in increasing customer loyalty.

\section{Literature Review}

\subsection{Private Brand / Private Label}

Many retailors nowadays are depending on the concept of private brands in order to increase their income. The reason for this dependency is attributed to the fact that private labels are cost effective, it means that private labels doesn't cost as much as regular labels do so retailors chose to design their own label and sell it to their customers due to their ability to manufacture the item in house based on their own specifications and their customer base would help them promote this label. According to Vargas-Hernandez and Noruzi Reza (201, 95) private label is defined as "products produced by one manufacturer and sold under the name of a different company". Xu et al. $(2018,4)$ saw that private labels can be defined as "also called store brands, are products produced by, or in the name of the distributor and sold under the distributor's own name and store".

Kokilavizhi and Vanitha (2018) stated that the PLMA - Private Label Manufactures Association founded in 1979 in America and aimed at organizing the flow of private labeling in order for them to be included under its territory and manage all labels to be sold and processed under the retailors' brand. The association has opened the chances for manufacturers to choose the brand name to either be the manufacturer name or any other 
name chosen by the manufacturer limited by the declaration that this brand belongs to this certain manufacturer. Chakraborty (2013) noted that private labels are normally items/services or products that are manufactured or provided by certain company but promoted for in the name of another company. With the development of private labels all over the world, there are a wide range of private labels that included foods, cosmetic, cars, furniture and even web hosting.

There are many factors that influence customers' satisfaction and loyalty towards PL; among these aspects are (products, Prices and Store). Zain et al. (2016) stated that product is influential as the quality of the product is among the aspects that may push customers towards purchasing private brand specifically if they have received their needs and desires. Weka, et al. (2019) stated that" The consumer perceptions and preferences are based on aroma, taste, texture, and color". Casas Arizon (2017) noted that price is among the influential aspects that may change the customers' intention to purchase a private label. Kremer and Viot (2012) focused on the store in attracting customers to private labels referring to it as more influential.

\subsection{Customer Loyalty}

When Reddy and Gowrishankar (2019) examined the customer satisfaction private labels; they have stated that among the challenges that may face customer satisfaction towards certain private labels is customer loyalty. Authors saw that the idea of customer loyalty is one of the most influential aspects that may have hindered the developments of customer satisfaction regarding a certain private label. They have also added that loyalty towards private labels can only be reached when the organization sores a high level of customer satisfaction.

On the other hand, Abdullah et al. (2012) tried to examine the influence of customer loyalty on purchasing private labels. Depending on quantitative approach authors found out that (product, price and store) are influential on customers' loyalty, however, product quality appeared to be the most influential given that customers become more loyal when they get eh best service that matches what they have paid for.

\subsection{Customer Satisfaction}

Khadka and Maharjan (2017) defined customer satisfaction as the overall evaluation that a customer reach to through their process from purchasing in item/ service or product, through consumption and reaching the after-sale service. Many studies have focused on the relationship between customer satisfaction and private labels. Khadka and Maharjan (2017) in their study tried to examine the customers" perception and satisfaction of private labels. Depending on quantitative approach; total of (293) individuals responded to the questionnaire revealing that they were satisfied regarding private labels due to its low cost, better quality and their trust in the brand they are dealing with.

In a study by Reddy and Gowrishankar (2019); authors aimed at examining the level of customer satisfaction regarding private label. Through the study; authors have employed the secondary data regarding the main problem which were gathered from different previous articles. Authors indicated that private label is satisfactory for those who are considered to be lifelong customers to a certain manufacturer and who are willing to try any product that has been developed by this certain organization. Generally speaking, it was revealed that private label influences customer satisfaction when the organization is running a well-built customer-based management that is able to attract their customers regardless of the change in their orientation. Another study by Casas Arizon (2017) who tried to examine customers' satisfaction and intention to purchase private labels items ad products and through distributing (252) questionnaire on a convenient sample; results of study indicated that private labels are met by customers with acceptance and intention to use due to their value and quality.

\section{Methods}

Current study depended on quantitative approach. The main tool of study was a questionnaire distributed on (250) individuals who are shopping in different malls, commercial complexes and retail stores. The After the application process researchers were able to retrieve (197) properly filled questionnaires which indicated a response rate of $(78.8 \%)$. The questionnaire consisted of two main sections; the first took into perspective the demographics of the sample (age, gender, academic qualification, job title and income), while the other was related to the study's main variables (PL, CS and CL).

\section{Results and Discussion 4.1 Statistical Analysis and Tastings}


Table 1. Sample characteristics according to demographic variables

\begin{tabular}{|c|c|c|c|c|c|}
\hline \multicolumn{6}{|c|}{ AGE } \\
\hline & & Freq. & Percent & Valid Percent & Cumulative Percent \\
\hline \multirow[t]{5}{*}{ Valid } & -30 & 63 & 32.0 & 32.0 & 32.0 \\
\hline & $30-45$ & 72 & 36.5 & 36.5 & 68.5 \\
\hline & $46-60$ & 46 & 23.4 & 23.4 & 91.9 \\
\hline & +61 & 16 & 8.1 & 8.1 & 100.0 \\
\hline & Total & 197 & 100.0 & 100.0 & \\
\hline \multicolumn{6}{|c|}{ SEX } \\
\hline & & Freq. & Percent & Valid Percent & Cumulative Percent \\
\hline \multirow[t]{3}{*}{ Valid } & Male & 83 & 42.1 & 42.1 & 42.1 \\
\hline & Female & 114 & 57.9 & 57.9 & 100.0 \\
\hline & Total & 197 & 100.0 & 100.0 & \\
\hline \multicolumn{6}{|c|}{ EDUCATION } \\
\hline & & Freq. & Percent & Valid Percent & Cumulative Percent \\
\hline \multirow[t]{5}{*}{ Valid } & $\begin{array}{l}\text { Secondary or } \\
\text { less }\end{array}$ & 62 & 31.5 & 31.5 & 31.5 \\
\hline & Diploma & 43 & 21.8 & 21.8 & 53.3 \\
\hline & $\mathrm{BA}$ & 76 & 38.6 & 38.6 & 91.9 \\
\hline & $\begin{array}{l}\text { Post } \\
\text { Graduates }\end{array}$ & 16 & 8.1 & 8.1 & 100.0 \\
\hline & Total & 197 & 100.0 & 100.0 & \\
\hline \multicolumn{6}{|c|}{ JOB } \\
\hline & & Freq. & Percent & Valid Percent & Cumulative Percent \\
\hline \multirow[t]{6}{*}{ Valid } & House Wife & 54 & 27.4 & 27.4 & 27.4 \\
\hline & $\begin{array}{l}\text { Public sector } \\
\text { employee }\end{array}$ & 25 & 12.7 & 12.7 & 40.1 \\
\hline & Private Sector & 38 & 19.3 & 19.3 & 59.4 \\
\hline & Self employed & 47 & 23.9 & 23.9 & 83.2 \\
\hline & other & 33 & 16.8 & 16.8 & 100.0 \\
\hline & Total & 197 & 100.0 & 100.0 & \\
\hline \multicolumn{6}{|c|}{ SALARY } \\
\hline & & Freq. & Percent & Valid Percent & Cumulative Percent \\
\hline \multirow[t]{6}{*}{ Valid } & -500 & 68 & 34.5 & 34.5 & 34.5 \\
\hline & $501-750$ & 46 & 23.4 & 23.4 & 57.9 \\
\hline & $751-1000$ & 30 & 15.2 & 15.2 & 73.1 \\
\hline & $1001-1250$ & 30 & 15.2 & 15.2 & 88.3 \\
\hline & +1250 & 23 & 11.7 & 11.7 & 100.0 \\
\hline & Total & 197 & 100.0 & 100.0 & \\
\hline
\end{tabular}

Table (1) above highlighted sample characteristics according to variables; it appeared that the majority of the sample was less than 30 years old forming $32 \%$ of the sample with frequency of 63 individuals. As for gender, the majority of sample was females forming $57.9 \%$ with an educational level of bachelor's degree forming $38.6 \%$ of the sample. It also appeared that most of sample individuals were house wives $27.4 \%$ followed by self-employed individuals $23.9 \%$. As for income; it appeared that the majority of sample $34.5 \%$ had an income of less than 500 JOD followed by an income range of 501-1000 JOD forming $23.4 \%$ of the sample. 
Table 2. Variables' Analysis

\begin{tabular}{|l|c|r|r|r|r|}
\hline & $\mathrm{N}$ & $\begin{array}{c}\text { Mini } \\
\text { mum }\end{array}$ & $\begin{array}{c}\text { Maxi } \\
\text { mum }\end{array}$ & Mean & $\begin{array}{c}\text { Std. } \\
\text { Deviation }\end{array}$ \\
\hline products & 197 & 1.00 & 5.00 & 4.0244 & .83024 \\
\hline prices & 197 & 1.00 & 5.00 & 3.8147 & .93094 \\
\hline Stores & 197 & 1.00 & 5.00 & 3.9772 & .77310 \\
\hline Satisfaction & 197 & 1.00 & 5.00 & 4.1282 & .70693 \\
\hline Loyalty & 197 & 1.00 & 5.00 & 4.2162 & .65787 \\
\hline $\begin{array}{l}\text { Valid N } \\
\text { (listwise) }\end{array}$ & 197 & & & & \\
\hline
\end{tabular}

In table (2) analysis of variables response was done highlighting that there was a positive attitude of respondents towards the chosen variables as the mean of the paragraphs scored higher than the mean of the scale (3.00) referring to the results as a good indicator (see Appendices 1: Variables' Analysis).

\section{Reliability Test}

Through utilizing Cronbachs' alpha test on tool of study; the value was (0.97) which was greater than the accepted percentage of 0.60 (Caridi et al., 2010) referring to the tool as reliable and there was internal consistency (see Appendices 2: Reliability Test).

\section{Collinearity Statistics Test}

Table 3. Collinearity statistics test

\begin{tabular}{|l|c|c|}
\hline \multirow{2}{*}{ Model } & \multicolumn{2}{|c|}{ Collinearity Statistics } \\
\cline { 2 - 3 } & Tolerance & VIF \\
\hline Products & .231 & 4.338 \\
\hline Prices & .257 & 3.895 \\
\hline Stores & .297 & 3.365 \\
\hline
\end{tabular}

Table (3) above highlighted results of Multicollinearity between independent utilizing Collinearity statistics: and precisely (VIF) Tolerance and Variance Inflation Factor. The minimum acceptable cutoff value for tolerance is typically (0.10) as according to (Belsley, et al. 2005) and maximum acceptable cutoff value for the VIF is (10). In other words, to indicate no problem with multicollinearity tolerance value should not be less than (0.10) while VIF value should not be more than (10).According to table (3), (VIF) for every variable sored less than (10) referring to tolerance range of (0.231-0.297); this indicated the lack of any multicollinearity problem between the independent variables.

\section{Hypotheses Testing}

\section{H (1): There is a significant impact between PLB dimensions and Customer Satisfaction}

$H$ (2): There is a significant impact between PLB dimensions and Customer Loyalty

$H$ (3): There is a significant impact between Customer Satisfaction and Customer Loyalty

H (4): Customer Satisfaction mediates the relationship between PLB dimensions on Customer Loyalty

In order to test above hypothesis, Path analysis by using IBM SPSS Amos 21.0 program was used, and following results are found:

Table 4. Path Analysis

\begin{tabular}{|l|c|c|c|c|c|}
\hline RAMSEA & CFI & GFI & $\begin{array}{c}\text { p- } \\
\text { value }\end{array}$ & df & Chi $^{2}$ \\
\hline 0.026 & 0.999 & 0.991 & 0.34 & 4 & 4.521 \\
\hline GFI & $\geq 0.90$ \\
\hline CFI & $\geq 0.90$ \\
\hline RAMSEA & $\leq 0.08$ \\
\hline
\end{tabular}

In order to test the structural model fit, the value of $\mathrm{X}^{2}=4.521$ is not significant at $0.05,(\mathrm{GFI}=0.991)$ is an excellent indicator, the CFI $=0.999$ is an excellent value, (RAMSEA $=0.026$ ) is an acceptable value.

That means the structural model is fit.

As Shown in the following table, study Hypotheses were supported:

Table 5. Amos Results

\begin{tabular}{|l|l|l|r|r|r|r|}
\hline & & & Estimate & S.E. & C.R. & P** \\
\hline Satisfaction & $<--$ & F1 & .877 & .054 & 16.380 & $* * *$ \\
\hline Loyalty & $<--$ & F1 & .435 & .100 & 4.331 & $* * *$ \\
\hline Loyalty & $<--$ & Satisfaction & .298 & .093 & 3.195 & .001 \\
\hline
\end{tabular}

- F1:PLB Variable

- ** Significant at 0.05 level 
Table 6. Estimates for direct and indirect impact

\begin{tabular}{|l|c|c|c|c|}
\hline & & $\begin{array}{c}\text { Standardized } \\
\text { Indirect } \\
\text { Effects }\end{array}$ & $\begin{array}{c}\text { Standardized } \\
\text { Total Effects }\end{array}$ \\
\hline $\begin{array}{l}\text { Standardized Direct Effects } \\
\begin{array}{l}\text { PLB } \longrightarrow \text { Customer } \\
\text { Satisfaction }\end{array}\end{array}$ & 0.848 & $0.000^{* *}$ & & 0.848 \\
\hline $\begin{array}{l}\text { Customer Satisfaction } \\
\longrightarrow \text { Customer Loyalty }\end{array}$ & 0.32 & $0.001^{* *}$ & & 0.32 \\
\hline $\begin{array}{l}\text { PLB } \longrightarrow \text { Customer } \\
\text { Loyalty }\end{array}$ & 0.452 & $0.000^{* *}$ & 0.272 & 0.724 \\
\hline
\end{tabular}

** Significant at 0.05 level

Table (6) shows that C.R. Values are significant at 0.05 levels that means:

- There is a significant impact between PLB dimensions and Customer Satisfaction

- There is a significant impact between PLB dimensions and Customer Loyalty

- There is a significant impact between Customer Satisfaction and Customer Loyalty

Also it was found that Standardized Indirect Effect of Customer Satisfaction was significant at 0.05 level, that means Customer Satisfaction mediates the relationship between PLB dimensions on Customer Loyalty, as shown in the following chart:

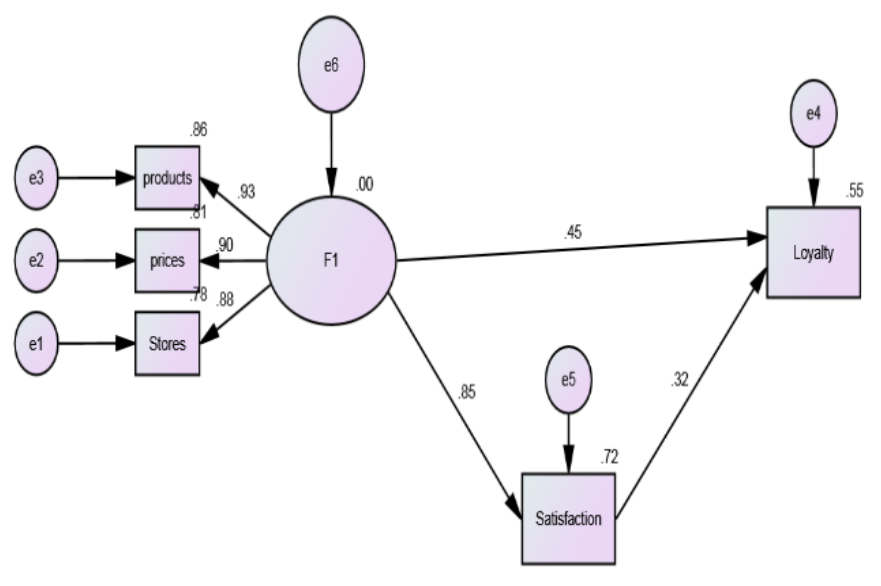

Fig.1 Path analysis

\section{Discussion}

Results of study indicated an influence of private label on customer satisfaction which in its turn can influence loyalty of customers. As a start, demographic results indicated that majority of sample was females who are either self-employed or house wives with an income of less than 500 JOD or between 501-1000 JOD. Results seemed to be valid given than females are more into shopping and caring of brands compared to males. Through testing the influence of dependent variables; it appeared that private label brand has the ability to influence customer satisfaction leading to better loyalty. Results were attributed to product followed by store and the least influencing appeared to be price. Results were seen to be logical given that once a customer is satisfied with the product itself and its quality, in addition to the store and price there would be a better chance to develop loyalty towards the brand. Study results met what came along with Reddy and Gowrishankar (2019) who noted that the reason for the private label's ability to gain customer satisfaction is attributed to the fact that it can meet the customers' expectations and support them with the specifications of an item/service that they look for in a brand. Pilar Martinez-Ruiz et al. (2014) supported the same results arguing that after being satisfied with the brand customers are more willing to be loyal given the fact that the brand was able to support them with their needs and desires which makes them more leaning towards choosing the same brand all the time.

Looking through literature; it appeared that results of current study matched results of many previous studies which reached the overall theory that gaining customer satisfaction can lead to customer loyalty. In another meaning, the idea of gathering between customer satisfaction and customer loyalty is among the notions that appeared to be widely adopted and generally acceptable within more than one field. In order to gain the best loyalty from your customers; all you have to do is to gain their satisfaction through presenting the best and most accurate service quality there is in your brand. From that point, there appeared the importance of service quality in creating customer satisfaction. According to Mohsan et al. (2011) the main reason or organization's possession in gaining customer satisfaction is to make them more willing to choose the same brand all the time, this is a type of loyalty, when a customer choses the same brand all the time because they are satisfied with it then they are being loyal to this brand. The same appeared by Chinomona and Dubihlela (2014) who noted that it is widely known that customer satisfaction leads to customer loyalty as satisfaction from a certain brand can help in developing the overall image towards the brand, increase the level of security and trust regarding it and make customer always willing to take the same purchase decisions all the time. Ibojo (2015) noted that the reason for gathering between customer satisfaction and customer loyalty is attributed to the fact that they are both related to the concept of customer behavior. Both of these behaviors are - if managed in a smart way - can play a role in increasing the 
level of trust and retention of customers in order to gain the best customer based and manage it for the best of the organization. Awan and Rehman (2014) also supported the results above and added that private labels are mostly influenced by the gathering between satisfaction and loyalty given that the private brand is more able to control its specifications and characteristic to reach more customer satisfaction which leads to loyalty, because increasing the degree of satisfaction toward any private brand will lead to increase the loyalty level for each customer.

\section{Conclusion}

The brand plays a large and important role in the commercial field in all countries of the world, especially in the field of internal and external trade. It has been agreed to define the brand as all that distinguishes a product or service from other similar or similar goods or services. The brands take forms and are made up of many elements that are difficult to enumerate.

Therefore, in most trademark legislation and methods of protection, the legal legislator cited examples of what the trademark might include names, figures, drawings, symbols, addresses of shops, prominent inscriptions and a group of colors that take a special form, as well as any combination of these elements. Generally speaking, a private brand it based on taking extra measure to present a brand with the best and most accurate quality and price; this has the ability to attract customer and increase their satisfaction which in its turn can influence their loyalty towards the brand.

The private label is more flexible, resilient, and lean to match and react to all changes that may appear in the market. It has the ability to disguise itself in accordance with the universal trends that keeps changing through the time. From that point, there is a better chance for private labels to increase customers' loyalty through focusing on meeting their desires and needs so as to reach the best level of satisfaction.

Based on study results, discussion and conclusion, it was recommended to employ the flexibility of private labels for the benefit of the organization and develop the level of service quality that is presents in order to be able to support its customers with their needs and desires, in addition to attract more potential customers and increase the level of customer retention. Also, Private label is all about the image, there is a need to focus more on the image of the brand in accordance with the customers; preferences in order to increase its chances in the market.

\section{References:}

[1] Abdullah, R. B., Ismail, N. B., Rahman, A. F. B. A., Suhaimin, M. B. M., Safie, S. K. B., Tajuddin, M. T. H. M., ... \&Zain, R. A. (2012). The relationship between store brand and customer loyalty in retailing in Malaysia. Asian Social Science, 8(2), 171-184.

[2] Awan, A. G., \&Rehman, A. U. (2014). Impact of customer satisfaction on brand loyalty: An empirical analysis of home appliances in Pakistan. British Journal of Marketing Studies, 2(8), 18-32.

[3] Burnes, J and Pepe, M. (2016). Store Brands and National Brands Price Differential and Impact on Category Performance, Journal of Business and Economics, 7(3), 474-481

[4] Casas Arizon, L. D. (2017). Is it a matter of trust?: customer purchase intention and satisfaction of private label brands.

[5] Chakraborty, S. (2013). Private-label brands-a literature review. SIT Journal of Management, 3, 75-88.

[6] Chinomona, R., \&Dubihlela, D. (2014). Does customer satisfaction lead to customer trust, loyalty and repurchase intention of local store brands? The case of Gauteng Province of South Africa. Mediterranean Journal of Social Sciences, 5(9), 23.

[7] Ibojo, B. O. (2015). Impact of Customer Satisfaction on Customer Retention: A Case Study of a Reputable Bank in Oyo, Oyo State. Nigeria. International Journal of Managerial Studies and Research (IJMSR), 3(2), 42-53.

[8] Khadka, K., \&Maharjan, S. (2017). Customer satisfaction and customer loyalty: Case trivselstädtjänster (trivselsiivouspalvelut).

[9] Kokilavizhi, S and Vanitha, R. (2018). Consumer Perception and Satisfaction on Private Label Brand, International Journal of Interdisciplinary Research and Arts and Humanities, 3(1)

[10] Kremer, F., \&Viot, C. (2012). How store brands build retailer brand image. International Journal of Retail \& Distribution Management, 40(7), 528-543.

[11] Kumar, S., \& Kothari, M. (2015). A study on consumer perception regarding private label branding in India. European Journal of Business and Management, 7(10), 225-232.

[12] Mohsan, F., Nawaz, M. M., Khan, M. S., Shaukat, Z., \&Aslam, N. (2011). Impact of customer satisfaction on customer loyalty and 
intentions to switch: Evidence from banking sector of Pakistan. International Journal of Business and Social Science, 2(16).

[13] Pilar Martinez-Ruiz, M., Ruiz-Palomino, P., Martinez-Canas, R., \& José Blázquez-Resino, J. (2014). Consumer satisfaction and loyalty in private-label food stores. British Food Journal, 116(5), 849-871.

[14] Reddy, K and Gowrishankar, K. (2019). Customer Satisfaction on Private Lebel, International Journal of Engineering Development and Research, 7(1)

[15] Vargas-Hernandez, J., \&Noruzi Reza, M. (2011). A Study on Different Perspectives on Private Labels. International Journal of Humanities and Social Science, 1(2), 95-97.

[16] Weka G., Abdullah, Ilma S., Usman, R., Sri, W., Rh, F., , Wa , B., Weka, W. \& Zulfikar,
(2019).Consumer Preferences of Functional Powdered Drink based on Palm Sugar, WSEAS Transactions on Environment and Development, Volume 15, 570-577

[17] Xu, J. Huang, R and Ji, Y. (2018). Private Labels in China-Cases Tudies of RT-MART and ICA. Available online: chromeextension://oemmndcbldboiebfnladdacbdfmad $\mathrm{adm} / \mathrm{http}: / / \mathrm{hb}$.divaportal.org/smash/get/diva2:1201139/FULLTE XT01.pdf. Accessed 22nd July 2019.

[18] Zain, O. M., \& Saidu, M. B. (2016). The Customers Satisfaction on Retailers' Brand Products: A Study on Selected Areas in Klang Valley. Procedia Economics and Finance, 35, 418-427. 


\section{Appendix}

\begin{tabular}{|c|c|c|c|c|c|}
\hline & $\mathrm{N}$ & $\begin{array}{l}\text { Minimu } \\
\mathrm{m}\end{array}$ & $\begin{array}{l}\text { Maximu } \\
\mathrm{m}\end{array}$ & Mean & $\begin{array}{c}\text { Std. } \\
\text { Deviation }\end{array}$ \\
\hline \multicolumn{6}{|c|}{ Products } \\
\hline High quality products & 197 & 1 & 5 & 4.15 & 1.019 \\
\hline Healthy and nutritional products & 197 & 1 & 5 & 4.09 & 1.031 \\
\hline Superior taste & 197 & 1 & 5 & 4.11 & .955 \\
\hline Safe and less risky products & 197 & 1 & 5 & 4.14 & .902 \\
\hline Fresh and daily products & 197 & 1 & 5 & 4.13 & .897 \\
\hline More durability and lasts longer & 197 & 1 & 5 & 3.88 & 1.041 \\
\hline Has a good appearance & 197 & 1 & 5 & 4.05 & 1.037 \\
\hline $\begin{array}{l}\text { Natural and free from preservatives and } \\
\text { chemicals }\end{array}$ & 197 & 1 & 5 & 3.92 & 1.085 \\
\hline Packaging is attractive and functional & 197 & 1 & 5 & 3.99 & 1.076 \\
\hline $\begin{array}{l}\text { I can purchase the quantity that suitable to } \\
\text { my needs }\end{array}$ & 197 & 1 & 5 & 3.79 & 1.095 \\
\hline \multicolumn{6}{|l|}{ 20 } \\
\hline Prices are reasonable and affordable & 197 & 1 & 5 & 3.78 & 1.115 \\
\hline I can get more quantity with a same price & 197 & 1 & 5 & 3.86 & .972 \\
\hline High price premiums & 197 & 1 & 5 & 3.86 & 1.040 \\
\hline Prices are competitive & 197 & 1 & 5 & 3.76 & 1.148 \\
\hline \multicolumn{6}{|c|}{ Stores } \\
\hline The store enjoys a favorable reputation & 197 & 1 & 5 & 4.05 & .946 \\
\hline Has a good experience & 197 & 1 & 5 & 3.99 & .901 \\
\hline Location is Convenience & 197 & 1 & 5 & 3.98 & .917 \\
\hline $\begin{array}{l}\text { Easy to find what I need because of wide } \\
\text { range of products }\end{array}$ & 197 & 1 & 5 & 3.96 & .900 \\
\hline $\begin{array}{l}\text { The store offers high levels of service and } \\
\text { convenience }\end{array}$ & 197 & 1 & 5 & 3.96 & .889 \\
\hline $\begin{array}{l}\text { The physical environment ( store design, } \\
\text { cold storage, cleanliness, atmosphere...) } \\
\text { is visually appealing }\end{array}$ & 197 & 1 & 5 & 3.90 & 1.067 \\
\hline \multicolumn{6}{|c|}{ Customer Satisfaction } \\
\hline I am contended with the product & 197 & 1 & 5 & 4.10 & .875 \\
\hline I am satisfied with the product & 197 & 1 & 5 & 4.01 & 1.076 \\
\hline I am pleased to purchase the product & 197 & 1 & 5 & 4.16 & .839 \\
\hline The product always meets my expectation & 197 & 1 & 5 & 4.25 & .752 \\
\hline \multicolumn{6}{|c|}{ Loyalty } \\
\hline I am very loyal to this product & 197 & 1 & 5 & 4.03 & .994 \\
\hline This product will be my first choice & 197 & 1 & 5 & 4.34 & .715 \\
\hline $\begin{array}{l}\text { In the future, I plan to purchase the same } \\
\text { product }\end{array}$ & 197 & 1 & 5 & 4.13 & .949 \\
\hline $\begin{array}{l}\text { I will speak proudly and positively about } \\
\text { the product }\end{array}$ & 197 & 1 & 5 & 4.13 & .865 \\
\hline $\begin{array}{l}\text { I will encourage others to purchase the } \\
\text { same product }\end{array}$ & 197 & 1 & 5 & 4.45 & .710 \\
\hline Valid N (listwise) & 197 & & & & \\
\hline
\end{tabular}


Appendix 2. Reliability Test

\begin{tabular}{|l|c|c|}
\hline Variables & Cronbach's alpha value & Items \\
\hline Private Label Dimensions & 0.966 & $1-20$ \\
\hline products & 0.945 & $1-10$ \\
\hline Prices & 0.892 & $11-14$ \\
\hline Stores & 0.905 & $15-20$ \\
\hline Customer Satisfaction & $\mathbf{0 . 8 0 1}$ & $\mathbf{2 1 - 2 4}$ \\
\hline Customer Loyalty & $\mathbf{0 . 8 2 8}$ & $\mathbf{2 5 - 2 9}$ \\
\hline
\end{tabular}

